\title{
Heavy Metals and Mineral Elements Not Included on the Nutritional Labels in Table Olives
}

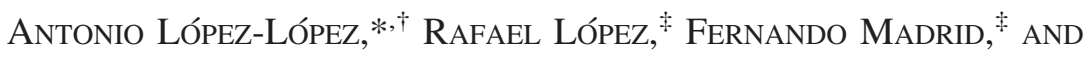 \\ ANTONIO GARRIDO-FERNÁNDEZ ${ }^{\dagger}$ \\ Instituto de la Grasa (CSIC), Avda. Padre García Tejero, 4, and IRNAS (CSIC), Avda. Reina \\ Mercedes, 10, Sevilla, Spain
}

\begin{abstract}
The average contents, in $\mathrm{mg} / \mathrm{kg}$ edible portion (e.p.), of elements not considered for nutritional labeling in Spanish table olives were as follows: aluminum, 71.1; boron, 4.41; barium, 2.77; cadmium, 0.04; cobalt, 0.12; chromium, 0.19; lithium, 6.56; nickel, 0.15; lead, 0.15; sulfur, 321; tin, 18.4; strontium, 9.71; and zirconium, 0.04. Sulfur was the most abundant element in table olives, followed by aluminum and tin (related to green olives). There were significant differences between elaboration styles, except for aluminum, tin, and sulfur. Ripe olives had significantly higher concentrations ( $\mathrm{mg} / \mathrm{kg}$ e.p.) of boron (5.32), barium (3.91), cadmium (0.065), cobalt (0.190), chromium (0.256), lithium (10.01), nickel (0.220), and strontium (10.21), but the levels of tin (25.55) and zirconium (0.039) were higher in green olives. The content of contaminants (cadmium, nickel, and tin) was always below the maximum limits legally established. The discriminant analysis led to an overall $86 \%$ correct classification of cases $(80 \%$ after cross-validation).
\end{abstract}

KEYWORDS: Canonical analysis; discriminant analysis; heavy metals; minerals; principal component analysis; table olives

\section{INTRODUCTION}

The release of hazardous pollutants into the environment persistently increases metal concentrations, thus contaminating the food supply. Metal contamination can take place during handling and processing. There is a general concern about the presence of heavy metals in foods, and tolerable daily intakes (TDIs) for some of them have been established (1-3). One of the first studies on heavy metals in food was reported by Mahaffey et al. (4). A survey on food contamination by metals in the European Union showed that consumer exposure to $\mathrm{Pb}$, $\mathrm{Cd}, \mathrm{As}$, and $\mathrm{Hg}$ was superior to the TDI (5). An assessment of dietary exposure to $\mathrm{As}, \mathrm{Cd}, \mathrm{Pb}$, and $\mathrm{Hg}$, for which maximum limits (MLs) were established in the Commission Regulation 466/2001, showed that they were generally below MLs (6). A survey on the content and daily intake of $\mathrm{Cu}, \mathrm{Zn}, \mathrm{Pb}, \mathrm{Cd}$, and $\mathrm{Hg}$ from dietary supplements in México (7) indicated that their estimated daily intakes were lower that those recommended by the WHO (3) and the Institute of Medicine (2). A recent survey in the market basket for $\mathrm{Pb}, \mathrm{Cd}, \mathrm{Cu}$, and $\mathrm{Zn}$ in Egyptian fruits and vegetables showed that they did not constitute a health hazard for consumers (8). The trace elements in other foodstuffs like cereals (9), bitter orange (10), or vegetables (11) have also been studied.

* To whom correspondence should be addressed. Tel: +34 954692516 . Fax: +34 954691262. E-mail: all@ cica.es.

${ }^{\dagger}$ Instituto de la Grasa (CSIC).

‡IRNAS (CSIC).
The consumption of table olives in the Mediterranean Basin is a widespread tradition, which is also reaching other nonproducing countries (12). Olives must be processed before eating to remove their natural bitterness (13). They are processed according to several styles (14). Green olives are treated with lye, washed, and fermented; ripe olives, darkened by oxidation after a storage period, are lye treated, washed several times, and packed; other olives are brined directly. All of them use salt in different proportions as the principal preservation agent (13). The different aqueous treatments may produce changes in the mineral composition of the processed fruits. Most of the studies related to the mineral content in table olives have been focused on mineral nutrients. Nosti Vega et al. (15) and De Castro Ramos et al. (16) studied processed samples from the Spanish cultivars, while Ünal and Nergiz (17) and Biricik and Basoglu (18) reported values from Turkish cultivars. Recently, the contents in $\mathrm{Na}, \mathrm{K}, \mathrm{Ca}, \mathrm{Mg}, \mathrm{Cu}, \mathrm{Zn}, \mathrm{Mn}, \mathrm{Fe}$, and $\mathrm{P}$, all of them nutrient minerals, in Spanish table olives were published (19). However, information on the presence of other minerals not required for nutritional labeling in table olives is scarce. The Trade Standards Applying to Table Olives (20) does not have specific limits for any element not used as an additive or processing aid. The determinations of $\mathrm{Mg}, \mathrm{Cr}, \mathrm{Co}, \mathrm{Ni}, \mathrm{Fe}, \mathrm{Cu}$, $\mathrm{Zn}, \mathrm{Sn}, \mathrm{Cd}$, and $\mathrm{Pb}$ in black and green olive samples from Turkey, reported by Şahan et al. (21), are the only available data. However, because of the diversity of commercial presentations in the market (which differ in processing styles, final conditioning, stuffing materials, preservation technologies, and 
Table 1. Overall and According to Elaboration Style Element Content (Mean \pm Standard Error) in Table Olives ${ }^{a}$

\begin{tabular}{|c|c|c|c|c|c|c|}
\hline metal & overall mean $(n=199)$ & green $(n=142)$ & directly brined $(n=27)$ & ripe $(n=30)$ & $F$ value $^{b}$ & $P$ value \\
\hline B & $4.41 \pm 0.12$ & $4.34 \pm 0.13$ & $3.72 \pm 0.23$ & $5.33 \pm 0.41$ & 7.46 & 0.001 \\
\hline $\mathrm{Ba}$ & $2.77 \pm 0.10$ & $2.78 \pm 0.10$ & $1.48 \pm 0.12$ & $3.91 \pm 0.33$ & 27.02 & 0.002 \\
\hline Co & $0.119 \pm 0.004$ & $0.106 \pm 0.002$ & $0.105 \pm 0.006$ & $0.190 \pm 0.016$ & 52.90 & 0.000 \\
\hline $\mathrm{Cr}$ & $0.195 \pm 0.007$ & $0.196 \pm 0.008$ & $0.122 \pm 0.006$ & $0.256 \pm 0.025$ & 13.92 & 0.000 \\
\hline $\mathrm{Li}$ & $6.55 \pm 0.48$ & $5.66 \pm 0.46$ & $7.41 \pm 1.25$ & $10.01 \pm 1.87$ & 5.72 & 0.004 \\
\hline$S$ & $320 \pm 10$ & $320 \pm 10$ & $330 \pm 20$ & $330 \pm 30$ & 0.22 & 0.803 \\
\hline Sn & $18.42 \pm 3.02$ & $25.55 \pm 4.09$ & $0.363 \pm 0.117$ & $0.936 \pm 0.142$ & 7.39 & 0.001 \\
\hline $\mathrm{Sr}$ & $9.71 \pm 0.20$ & $9.85 \pm 0.23$ & $8.46 \pm 0.46$ & $10.21 \pm 0.59$ & 3.38 & 0.036 \\
\hline $\mathrm{Zr}$ & $0.035 \pm 0.002$ & $0.039 \pm 0.002$ & $0.024 \pm 0.001$ & $0.029 \pm 0.004$ & 6.67 & 0.002 \\
\hline
\end{tabular}

${ }^{a}$ Results of the tests of equality of the group means are also included. Values are in $\mathrm{mg} / \mathrm{kg}$ e.p. ${ }^{b}$ Degrees of freedom for $F$ were 2 and 196.

cultivars), further studies for getting better knowledge on the mineral contents in table olives are necessary, especially of those elements not required for nutritional labeling. Such information should be of interest for consumers and for agencies in charge of the surveillance of the mineral and contaminant intake by consumers.

Chemometric techniques appear to be the most powerful tools for characterizing and classifying wines (22), honeys (23), dairy products (24), pistachios (25), and beer (26) according to their source, processing conditions, or origin. Among the most commonly used methods are principal component analysis (PCA) and discriminant analysis (DA), which usually include a canonical analysis. Recently, the application of multielement analysis and its chemometric study has been suggested for tracing the geographical origin of foods (27).

The aim of this work was to (i) determine the $\mathrm{Al}, \mathrm{B}, \mathrm{Ba}, \mathrm{Cd}$, $\mathrm{Co}, \mathrm{Cr}, \mathrm{Li}, \mathrm{Ni}, \mathrm{Pb}, \mathrm{S}, \mathrm{Sn}, \mathrm{Sr}$, and $\mathrm{Zr}$ contents in most relevant Spanish commercial presentations of table olives; (ii) check differences in the concentrations of such minerals due to processing styles and cultivars; and (iii) perform a chemometric study of the data to identify possible trends and to test the classification results with respect to those that could be obtained by chance.

\section{MATERIALS AND METHODS}

Samples. Samples $(n=199)$ belonged to the following styles, cultivars, and commercial presentations. Green Spanish-style olives: Gordal: plain, pitted, and seasoned; Gordal stuffed with red pepper strips, natural red pepper, almond, cucumber, onions, garlic, and jalapeño; and a blend of Gordal olives and red pepper strips called "salads". Manzanilla: plain, pitted, sliced, anchovy-flavored, and plain seasoned; Manzanilla stuffed with red pepper strips, anchovy strips, marinated anchovy strips, natural red pepper, almond, almond and red pepper, salmon strips, tuna strips, onions, capers, garlic, hazelnut, hot pepper, hot pepper strips, "piquillo" pepper, lemon paste, ham paste, orange strips, cheese, "jalapeño" strips, and garlic strips; a blend of pitted or slices of Manzanilla olives with red pepper strips called "pitted salads" and sliced "salads", respectively; a blend of Manzanilla olives with slices of carrot added called "gazpachas"; and a blend of Manzanilla olives and capers called "alcaparrado". Carrasqueña: pitted; a blend of pitted Carrasqueña olives and red pepper strips, called "salads"; and a blend of Carrasqueña olives and capers called "alcaparrado". Hojiblanca: plain, pitted, and sliced; and Hojiblanca olives stuffed with red pepper strips. Directly brined olives: Gordal: broken "seasoned" turning color. Manzanilla: turning color in brine alone, "seasoned" turning color, and olives from biologic (or organic) production. Hojiblanca: "seasoned" turning color. Arbequina: "seasoned" turning color. Aloreña: green "seasoned" broken, prepared from fresh fruits and from stored olives. Verdial: green "seasoned" broken.
Ripe olives (by alkaline oxidation): Gordal: plain. Manzanilla: pitted. Carrasqueña: plain and pitted. Hojiblanca: plain, pitted, and sliced. Cacereña: plain, pitted, and sliced.

Reagents. All reagents were of ultrapure analytical grade (Panreac, Barcelona, Spain). Hydrochloric acid $(6 \mathrm{~N})$ solution was obtained by dilution of concentrated $\mathrm{HCl}$ (Fluka, Buchs, Switzerland).

Cleaning of the Material. All glassware used for the determination of the mineral elements was immersed in $6 \mathrm{~N} \mathrm{HCl}$ overnight and then rinsed several times with distilled deionized water.

Sample Preparation. Analyses were carried out in triplicate on composite samples from each commercial presentation, which were made up of 3-8 units (cans, jars, or plastic pouches), depending on their sizes, and different packing dates, from 1-5 elaboration companies, according to their availability on market shelves. Producers kindly supplied those commercial presentations not available in the local markets. The average time from packing was about 3 months.

The pulp of $100 \mathrm{~g}$ of olive samples was separated from the pit, when necessary, by a manual or automatic pitting machine, ground, and homogenized. From the resulting paste mentioned above, $5 \mathrm{~g}$ of olive pulp ( $2.5 \mathrm{~g}$ for ripe olives) of the diverse samples was weighed exactly in a quartz capsule. The capsule was put in a muffle oven and incinerated at $550^{\circ} \mathrm{C}$. At this point, the temperature was quickly brought to $100{ }^{\circ} \mathrm{C}$ and then increased slowly until the ashing temperature was reached, which was maintained about $8-10 \mathrm{~h}$. The ashes, white-grayish in color, were slightly moistened and dissolved with three parts of 2 $\mathrm{mL}$ of $6 \mathrm{~N}$ ultrapure hydrochloric acid and filtered, bit by bit, through a filter paper into a $25 \mathrm{~mL}$ volumetric flask. After that, the filter was cleaned three times with $3 \mathrm{~mL}$ of deionized water, which was also added to the volumetric flask, and it was filled with deionized water until level. Dissolution was aided by slightly heating the capsule after every addition of hydrochloric acid. To ease filtration, a suction hood was used. At the same time, a blank was prepared with only the reagents.

Analytical Methods and Apparatus. The elements in sample extracts were determined by inductively coupled plasma-optical emission spectroscopy (Thermo Jarrell Ash IRIS Duo High Resolution ICP Spectrometer). A two point standardization $\left(1\right.$ and $10 \mathrm{mg} \mathrm{L}^{-1}$ ) was used to calibrate the spectrometer, except for $\mathrm{S}\left(20 \mathrm{mg} \mathrm{L}^{-1}\right)$. The standards were prepared in hydrochloric acid at the same concentration as in the samples. Interfering element correction factors were also applied to the applicable elements to compensate for any interference from $\mathrm{Al}$ and $\mathrm{Fe}$.

Analytical Quality Control. Sample 100 (grass 94) from WEPALIPE Programme (28) was used as a Certified Reference Material (CRM), and it was analyzed in triplicate. For the elements B, Ba, Cr, Li, Ni, S, $\mathrm{Sn}$, and $\mathrm{Sr}$, the obtained results agreed $\pm 5 \%$ with the certified results. For the elements $\mathrm{Al}, \mathrm{Cd}, \mathrm{Co}$, and $\mathrm{Pb}$, the obtained results agreed $\pm 10 \%$. There was no reported content for $\mathrm{Zr}$ in CRM.

Statistical Analysis. Each olive sample (object) was considered as an assembly of 13 variables represented by the $\mathrm{Al}, \mathrm{B}, \mathrm{Ba}, \mathrm{Cd}, \mathrm{Co}, \mathrm{Cr}$, $\mathrm{Li}, \mathrm{Ni}, \mathrm{Pb}, \mathrm{S}, \mathrm{Sn}, \mathrm{Sr}$, and $\mathrm{Zr}$ concentration in flesh (edible portion, e.p.). These variables formed a data vector, which represented an olive 
sample. Data vectors belonging to the same group (elaboration style or cultivar) were analyzed. The group was termed a category. The database from the analysis of minerals was thus arranged in a $199 \times$ 13 (cases $\times$ variables). Elaboration styles were coded as 1 (green Spanish style), 2 (directly brined), and 3 (ripe olives); cultivars were also coded as 1 (Gordal, G), 2 (Manzanilla, M), 3 (Carrasqueña, Cr), 4 (Hojiblanca, H), 5 (Arbequina, Ar), 6 (Aloreña, Al), 7 (Verdial, Vr), and 8 (Cacereña, $\mathrm{Cc}$ ).

Average values for cultivars within elaboration styles were obtained by the general linear model technique (nested analysis of variance, ANOVA). Data were also studied by multiple ANOVA (MANOVA) to test overall differences between groups across the different variable. These tests were carried out using original data. Diverse pattern recognition tools were used in this work.

Variables were also autoscaled (29) according to:

$$
\mathrm{y}_{m j}=\frac{\left(x_{m j}-\bar{x}_{m}\right)}{s_{m}}
$$

where $y_{m j}$ is the value $j$ for the variable $m$ after scaling, $x_{m j}$ is the value $j$ of the variable $m$ before scaling, $\bar{x}_{\mathrm{m}}$ is the mean of the variable $m$, and $s_{m}$ is the standard deviation for the variable $m$. The results were variables with zero mean and a unit standard deviation, which were later used for the chemometric study.

PCA is a standard tool in chemometrics for data compression to capture the main features in the multivariate data sets and to extract information from them (30). The analysis was carried out on the basis of the backward stepwise option. The values of probability to enter or to remove were fixed at 0.05 and 0.1 , respectively. The number of steps was fixed at 100 , the minimum tolerance was set at 0.01 , and no variable was forced to enter in any model (31).

Linear discriminant analysis (LDA) is a supervised technique that provides a classification model characterized by a linear dependence of the classification scores with respect to the descriptors (groups previously defined) (32). Two very distinct purposes and procedures for conducting DA exist as follows: discriminant predictive analysis (derivation of the linear discriminant functions) and discriminant classification analysis (to evaluate the previous linear functions to classify current and future samples). To measure the classification power of the analytical data, the percentage of individuals correctly predicted to belong to the assigned group is calculated, considering that prior probabilities are proportional to the number of samples in each group.

In this work, a leaving-one-out cross-validation procedure was performed for assessing the performance of the classification rule. In this procedure, the sample data minus one observation was used for the estimation of the discriminant functions, and then, the omitted sample was classified from them. The procedure was repeated for all samples. Consequently, each sample was classified by discriminate functions, which were estimated without its contribution (33).

The calculation of the confusion matrix has traditionally been the final step in the DA. However, the confusion matrix, when viewed as a contingency table, may be subject to further analysis, specifically with respect to the observed correct classification (34). In this work, we applied tests for overall classification, group classification (individual rows), and individual cells to compare the predicted classification using the model to that expected from chance alone.

The overall classification may be accomplished by the conventional $\chi^{2}$ test for a contingency table, in which

$$
\chi^{2}=\sum_{i} \sum_{j} \frac{\left(o_{i j}-e_{i j}\right)^{2}}{e_{i j}}
$$

where $o_{i j}$ is the observed number of samples classified in the cell $i j ; e_{i j}$ $=\left(n_{i .} \cdot n_{. j}\right) / n$ with $n_{i .}$ equal to the number of samples classified in row $i, n_{j}$ equal to the number of samples in column $j$, and $n$ equal to the total number of samples. As usual, the number of degree of freedom is $(i-1)(j-1)$.

The tests of group differences were achieved according to the Morrison (35) likelihood analysis, which provides a criterion that may be used to compare the proportion of correctly classified observations with the proportion expected by chance. The proportion expected by
Table 2. Element Content (Mean \pm Standard Error) in Green Spanish Style Olives, According to Cultivars ${ }^{a}$

\begin{tabular}{lcccc}
\hline metal & $\begin{array}{c}\text { Gordal } \\
n=32\end{array}$ & $\begin{array}{c}\text { Manzanilla } \\
n=90\end{array}$ & $\begin{array}{c}\text { Carrasqueña } \\
n=9\end{array}$ & $\begin{array}{c}\text { Hojiblanca } \\
n=11\end{array}$ \\
\hline $\mathrm{Al}$ & $85.89 \pm 9.11$ & $66.95 \pm 3.50$ & $83.67 \pm 4.86$ & $55.76 \pm 7.90$ \\
$\mathrm{~B}$ & $4.371 \pm 0.312$ & $4.20 \pm 0.14$ & $3.83 \pm 0.43$ & $5.84 \pm 0.42$ \\
$\mathrm{Ba}$ & $2.38 \pm 0.19$ & $2.86 \pm 0.13$ & $2.80 \pm 0.18$ & $3.27 \pm 0.41$ \\
$\mathrm{Cd}$ & $0.037 \pm 0.005$ & $0.035 \pm 0.003$ & $0.027 \pm 0.010$ & $0.031 \pm 0.007$ \\
$\mathrm{Co}$ & $0.109 \pm 0.005$ & $0.107 \pm 0.002$ & $0.093 \pm 0.011$ & $0.099 \pm 0.009$ \\
$\mathrm{Cr}$ & $0.189 \pm 0.020$ & $0.207 \pm 0.010$ & $0.122 \pm 0.009$ & $0.178 \pm 0.024$ \\
$\mathrm{Li}$ & $8.66 \pm 1.31$ & $4.38 \pm 0.40$ & $10.56 \pm 2.69$ & $3.47 \pm 0.71$ \\
$\mathrm{Ni}$ & $0.112 \pm 0.011$ & $0.161 \pm 0.014$ & $0.103 \pm 0.023$ & $0.154 \pm 0.041$ \\
$\mathrm{~Pb}$ & $0.262 \pm 0.082$ & $0.283 \pm 0.062$ & $0.331 \pm 0.093$ & $0.201 \pm 0.022$ \\
$\mathrm{~S}$ & $370 \pm 20$ & $290 \pm 10$ & $250 \pm 20$ & $450 \pm 30$ \\
$\mathrm{Sn}$ & $0.307 \pm 0.103$ & $40.01 \pm 5.940$ & $0.123 \pm 0.015$ & $1.390 \pm 0.279$ \\
$\mathrm{Sr}$ & $10.35 \pm 0.42$ & $9.29 \pm 0.28$ & $12.76 \pm 1.27$ & $10.58 \pm 0.58$ \\
$\mathrm{Zr}$ & $0.031 \pm 0.003$ & $0.039 \pm 0.003$ & $0.032 \pm 0.003$ & $0.062 \pm 0.009$ \\
& & & &
\end{tabular}

${ }^{a}$ Values are in $\mathrm{mg} / \mathrm{kg}$ e.p.

chance, designated the proportional chance criteria, is expressed as $c_{\text {pro }}$ $=p \cdot \alpha+(1-p)(1-\alpha)$, where $p=$ the true proportion of each style (or cultivar) in the total sample, and $\alpha=$ the proportion of each style (cultivar) in the whole sample categorized in that style (cultivar) by the model. This relationship between chance and observed proportions can be tested using a $Z$ statistic of the form:

$$
Z=\frac{p_{\mathrm{cc}}-c_{\text {pro }}}{\sqrt{\frac{c_{\text {pro }}\left(1-c_{\text {pro }}\right)}{n}}}
$$

where $p_{\mathrm{cc}}$ is the overall percent observations correctly classified in the sample.

The classification and misclassification within groups (cells in the confusion matrix), applied to determine the source of deviation, was conducted using the maximum chance criterion, $c_{\max }$, defined as the minimum expected correct classification for a select group of interest; the calculation of $c_{\max }$ is based on the assumption that all observations are categorized as coming from that group (35). A $Z$ statistic is used to test this relationship:

$$
Z_{i j}=\frac{o_{\mathrm{cc}}-c_{\max }}{\sqrt{\frac{c_{\max }\left(1-c_{\max }\right)}{n}}}
$$

where $o_{\mathrm{cc}}$ stands for observed correct (incorrect) classification of the specific cell. The test may be conducted for all of the cells in the confusion matrix. The different statistical techniques used in this work were implemented using STATISTICA, release 6.0 (36), and SYSTAT, release $10.2(31)$.

\section{RESULTS AND DISCUSSION}

Concentration of Minerals in Table Olives. The overall means (Table 1) as well as averages according to styles (Table 1) and cultivars within styles (Tables 2-4) in table olives were obtained using a nested ANOVA, which showed significant differences among styles for some elements (Figure 1). The most abundant elements were $\mathrm{S}$ and $\mathrm{Al}$, followed, at a marked distance, by $\mathrm{Sn}, \mathrm{Sr}, \mathrm{Li}, \mathrm{B}$, and $\mathrm{Ba}$; the remaining elements were in concentrations below $1 \mathrm{mg} / \mathrm{kg}$ e.p. (Table 1). The content of $\mathrm{S}$ ranged from $567 \mathrm{mg} / \mathrm{kg}$ e.p. in green Manzanilla olive stuffed with onion to $109 \mathrm{mg} / \mathrm{kg}$ e.p. in directly brined "seasoned" Hojiblanca, while the overall average was $320 \mathrm{mg} / \mathrm{kg}$ e.p. Differences among elaboration styles were not significant. The average $\mathrm{S}$ contents according to cultivars within elaboration styles are shown in Tables $\mathbf{2 - 4}$. The concentrations found in table olives were similar to those reported by Anderson et al. (37) in diverse vegetables. Aluminum contents, with an overall average of $71 \mathrm{mg} / \mathrm{kg}$ e.p., ranged from $204 \mathrm{mg} / \mathrm{kg}$ e.p. in plain 
Table 3. Element Content (Mean \pm Standard Error) in Directly Brined Olives, According to Cultivars ${ }^{a}$

\begin{tabular}{|c|c|c|c|c|c|c|}
\hline metal & Gordal $n=3$ & Manzanilla $n=10$ & Hojiblanca $n=2$ & Arbequina $n=3$ & Aloreña $n=6$ & Verdial $n=3$ \\
\hline B & $3.15 \pm 0.34$ & $4.21 \pm 0.27$ & $1.57 \pm 0.25$ & $3.22 \pm 0.24$ & $4.37 \pm 0.60$ & $3.27 \pm 0.44$ \\
\hline $\mathrm{Ba}$ & $1.30 \pm 0.23$ & $1.63 \pm 0.23$ & $1.86 \pm 0.78$ & $1.11 \pm 0.13$ & $1.35 \pm 0.31$ & $1.58 \pm 0.17$ \\
\hline Co & $0.121 \pm 0.002$ & $0.108 \pm 0.011$ & $0.085 \pm 0.041$ & $0.126 \pm 0.004$ & $0.099 \pm 0.019$ & $0.088 \pm 0.010$ \\
\hline $\mathrm{Cr}$ & $0.144 \pm 0.006$ & $0.128 \pm 0.009$ & $0.090 \pm 0.012$ & $0.162 \pm 0.017$ & $0.103 \pm 0.011$ & $0.100 \pm 0.007$ \\
\hline $\mathrm{Li}$ & $9.71 \pm 3.77$ & $5.99 \pm 2.20$ & $8.95 \pm 6.86$ & $12.21 \pm 4.67$ & $8.00 \pm 2.34$ & $2.84 \pm 0.97$ \\
\hline S & $300 \pm 26$ & $270 \pm 20$ & $150 \pm 50$ & $390 \pm 20$ & $410 \pm 20$ & $430 \pm 10$ \\
\hline Sn & $0.825 \pm 0.773$ & $0.303 \pm 0.110$ & $0.110 \pm 0.034$ & $1.088 \pm 0.581$ & $0.105 \pm 0.015$ & $0.060 \pm 0.011$ \\
\hline $\mathrm{Sr}$ & $7.09 \pm 0.92$ & $7.01 \pm 0.70$ & $8.47 \pm 2.54$ & $9.06 \pm 0.71$ & $11.17 \pm 0.69$ & $8.64 \pm 0.29$ \\
\hline $\mathrm{Zr}$ & $0.017 \pm 0.003$ & $0.029 \pm 0.005$ & $0.012 \pm 0.005$ & $0.009 \pm 0.003$ & $0.029 \pm 0.004$ & $0.026 \pm 0.004$ \\
\hline
\end{tabular}

${ }^{a}$ Values are in $\mathrm{mg} / \mathrm{kg}$ e.p.

Table 4. Element Content (Mean \pm Standard Error) in Ripe Olives, According to Cultivars ${ }^{a}$

\begin{tabular}{|c|c|c|c|c|c|}
\hline metal & Gordal $n=3$ & Manzanilla $n=3$ & Carrasqueña $n=6$ & Hojiblanca $n=9$ & Cacereña $n=9$ \\
\hline $\mathrm{Al}$ & $94.63 \pm 27.85$ & $63.80 \pm 9.48$ & $92.73 \pm 21.47$ & $70.38 \pm 6.48$ & $68.01 \pm 9.20$ \\
\hline$B$ & $2.80 \pm 0.56$ & $6.92 \pm 0.18$ & $4.20 \pm 0.34$ & $4.85 \pm 0.81$ & $6.86 \pm 0.73$ \\
\hline $\mathrm{Ba}$ & $3.35 \pm 0.51$ & $6.36 \pm 0.78$ & $3.29 \pm 0.86$ & $3.25 \pm 0.35$ & $4.34 \pm 0.64$ \\
\hline $\mathrm{Cd}$ & $0.064 \pm 0.059$ & $0.084 \pm 0.006$ & $0.048 \pm 0.012$ & $0.075 \pm 0.009$ & $0.060 \pm 0.012$ \\
\hline Co & $0.165 \pm 0.057$ & $0.255 \pm 0.010$ & $0.147 \pm 0.037$ & $0.206 \pm 0.028$ & $0.190 \pm 0.031$ \\
\hline $\mathrm{Cr}$ & $0.201 \pm 0.044$ & $0.279 \pm 0.104$ & $0.211 \pm 0.040$ & $0.291 \pm 0.067$ & $0.263 \pm 0.026$ \\
\hline $\mathrm{Li}$ & $19.03 \pm 0.56$ & $5.49 \pm 1.24$ & $12.35 \pm 5.88$ & $8.49 \pm 2.96$ & $8.47 \pm 3.70$ \\
\hline $\overrightarrow{\mathrm{Ni}}$ & $0.195 \pm 0.016$ & $0.261 \pm 0.051$ & $0.163 \pm 0.036$ & $0.234 \pm 0.049$ & $0.240 \pm 0.041$ \\
\hline $\mathrm{Pb}$ & $0.638 \pm 0.239$ & $0.317 \pm 0.035$ & $0.196 \pm 0.021$ & $0.216 \pm 0.047$ & $1.366 \pm 1.036$ \\
\hline S & $260 \pm 11$ & $410 \pm 40$ & $220 \pm 30$ & $390 \pm 40$ & $320 \pm 50$ \\
\hline Sn & $0.131 \pm 0.027$ & $0.538 \pm 0.091$ & $1.479 \pm 0.451$ & $1.080 \pm 0.295$ & $0.816 \pm 0.086$ \\
\hline $\mathrm{Sr}$ & $10.93 \pm 0.74$ & $11.03 \pm 0.12$ & $9.14 \pm 2.24$ & $11.61 \pm 0.80$ & $9.00 \pm 0.95$ \\
\hline $\mathrm{Zr}$ & $0.041 \pm 0.014$ & $0.042 \pm 0.018$ & $0.028 \pm 0.005$ & $0.030 \pm 0.006$ & $0.020 \pm 0.008$ \\
\hline
\end{tabular}

${ }^{a}$ Values are in $\mathrm{mg} / \mathrm{kg}$ e.p.

Gordal green olive to $17.5 \mathrm{mg} / \mathrm{kg}$ e.p. in Manzanilla green olives stuffed with natural pepper, but there were no significant differences among styles (which ranged from 64 to $76 \mathrm{mg} / \mathrm{kg}$ e.p.) (Table 1). However, differences among cultivars were significant. The lowest concentration was found in Arbequina (49 mg/kg e.p.), and the highest was found in Gordal (94 mg/ $\mathrm{kg}$ e.p.). Levels of $\mathrm{Al}$ in other foods are also high. Saiyed and Yokel (38) reported concentrations from 1 to $27000 \mathrm{mg} / \mathrm{kg}$ in selected foods in the United States, which contained Al as an approved food additive. Shafer and Seifert (39) found levels between 100 and $200 \mathrm{mg} / \mathrm{kg}$ dry matter in vegetables, herbs, and spices. Legumes and nuts had $2.7-48.5 \mathrm{mg} / \mathrm{kg}$ e.p. (40). Aluminum is used as an additive in the food industry, and numerous pharmaceutical preparations (antacids, analgesics, antiulceratives, and phosphate binders) (39). The Al presence was consistently high in table olives regardless of the elaboration process, so its origin must be the same raw material; however, the contents reported by Nergiz and Engez (41) for fresh olives from Domat and Memecik Turkish cultivars were markedly lower (0.9-7.3 $\mathrm{mg} / \mathrm{kg}$ e.p.).

The overall level (18.4 mg/kg e.p.) of Sn in Spanish table olives was mainly due to its presence in green olives, where it reached $25.5 \mathrm{mg} / \mathrm{kg}$ e.p. (Table 1). This is because some of these presentations are packed in microthin tin-coated cans to prevent corrosion; on the contrary, the mean contents in directly brined olives and ripe olives, which use lacquered cans, were markedly lower, 0.4 and $1 \mathrm{mg} / \mathrm{kg}$ e.p., respectively (Table 1). Furthermore, within green olives, the Manzanilla cultivar (average $40.0 \mathrm{mg} / \mathrm{kg}$ e.p.) was preferably packed in tin-coated cans, while Gordal, Carrasqueña, and Hojiblanca were not, as reflected by their low levels of $\operatorname{Sn}(0.31,0.12$, and 1.39 , respectively) (Table 2). Concentrations of Sn found by Şahan et al. (21) in green olives $(33.3-47.6 \mathrm{mg} / \mathrm{kg}$ e.p.) were markedly higher than those found in this work for the same style but similar to the levels detected in the green Manzanilla cultivar. The level reported by this author for black olives $(35.5 \mathrm{mg} / \mathrm{kg}$ e.p.) was markedly higher than that observed in directly brined olives in Spain (average $0.36 \mathrm{mg} / \mathrm{kg}$ e.p.). This may indicate the use of tin-coated cans for packing this product.

The Codex Alimentarius Commission regards tin as a priority contaminant. Food and especially canned foods represent the main source of human exposure to tin (42). Mean Sn values in this work were below the average reported by Wehrer (43) from more than 500 samples of canned food from retail sources (70 $\mathrm{mg} / \mathrm{kg}$ ); in this case, only $5 \%$ of the samples exceeded $250 \mathrm{mg} /$ $\mathrm{kg}$. The $\mathrm{Sn}$ concentration increased with storage time. The canned fruit or vegetable generally contained more Sn than the juice or brine in which they were packed (43). An average proportion of $90 \mathrm{mg} / \mathrm{kg}$ was found by Jorhem and Slorach (44) in fruits and vegetables packed in welded unlacquered cans. Concentrations found by Perring and Basic-Dvorzac (45) in diverse foodstuffs were between 58 and $113 \mathrm{mg} / \mathrm{kg}$ in fruits, between 2 and $30 \mathrm{mg} / \mathrm{kg}$ in vegetables, and especially high in beverages, $180-240 \mathrm{mg} / \mathrm{kg}$ (45).

The overall average of $\mathrm{Sr}$ was moderate $(9.71 \mathrm{mg} / \mathrm{kg}$ e.p.); its maximum level (19.8 $\mathrm{mg} / \mathrm{kg}$ e.p.) was found in the ripe Carrasqueña cultivar, while the lowest $(7.06 \mathrm{mg} / \mathrm{kg}$ e.p.) was observed in green Manzanilla stuffed with natural pepper. Data on the presence of this element in foods are scarce. A content similar to that of table olives has been reported in fruits of the elm $(7.68 \mathrm{mg} / \mathrm{kg})(46)$, but its level in Lithuanian honey was lower $(0.15 \mathrm{mg} / \mathrm{kg})(47)$. The $\mathrm{Sr}$ level in herbal tea products ranged from 1.5 to $212 \mathrm{mg} / \mathrm{kg}$ and from 0.08 to $2.35 \mathrm{mg} / \mathrm{L}$ in their infusions (48). Concentrations between 0.21 and $0.79 \mathrm{mg} /$ 

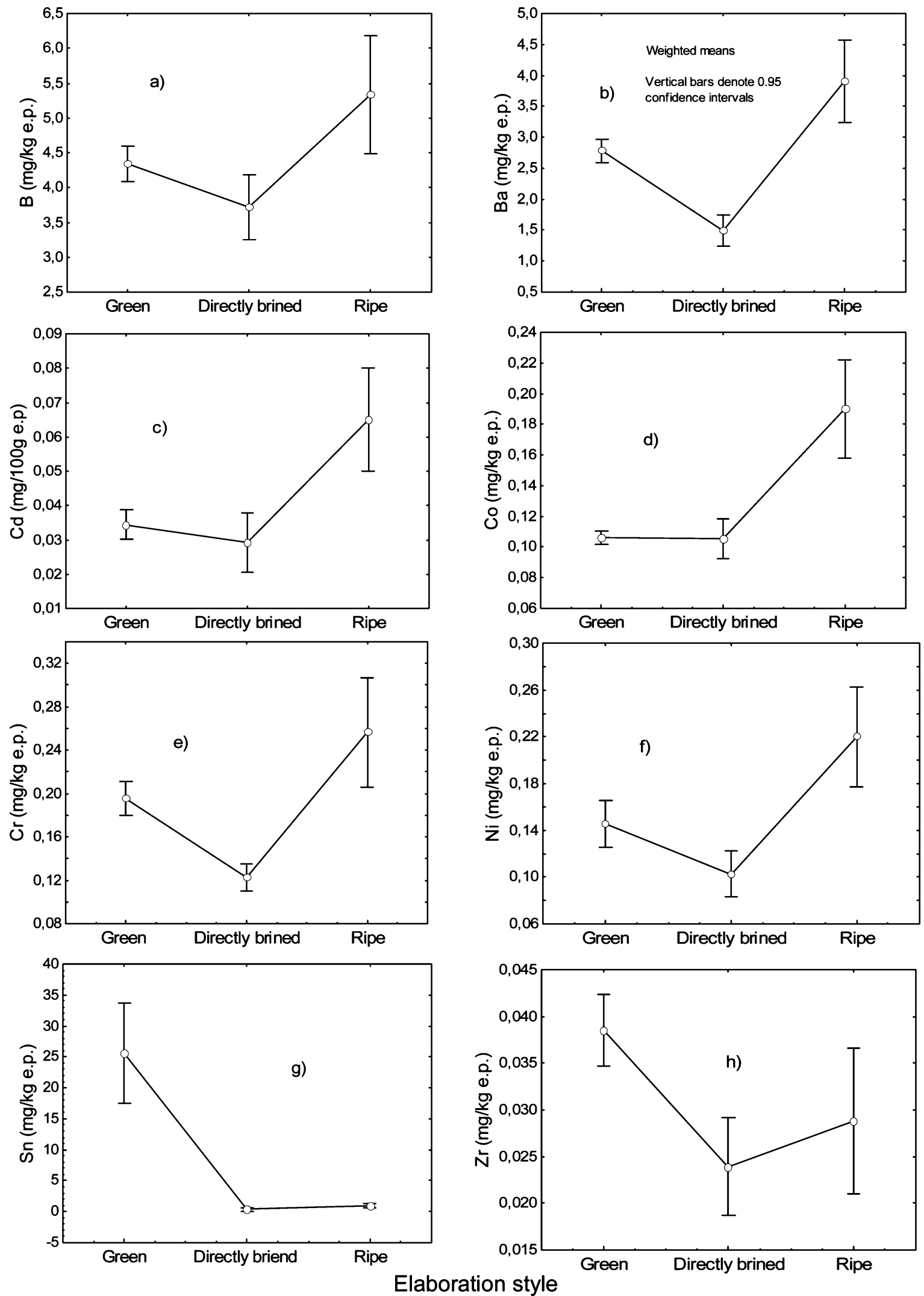

Figure 1. Mean values (mg/kg e.p.) and confidence limits $(P=0.05)$ of selected mineral elements, according to processing styles: (a) boron, (b) barium, (c) cadmium, (d) cobalt, (e) chromium, (f) nickel, (g) tin, and (h) zirconium. Elements were determined by IPC-OES.

$\mathrm{kg}$ or 1.16 and 4.63 were found in milk products and marine smoked fish (49).

Li was found in an overall mean of $6.55 \mathrm{mg} / \mathrm{kg}$ e.p., but its values were variable according to processing styles and cultivars. Its highest value $(36.8 \mathrm{mg} / \mathrm{kg}$ e.p.) was found in ripe $\mathrm{Ca}$ rrasqueña olives, and its lowest level $(0.23 \mathrm{mg} / \mathrm{kg}$ e.p. $)$ was found in "seasoned" green Manzanilla presentation. Data on Li in food are scarce. Nabrzyski and Gajewska (49) reported concentrations ranging from $<0.03-0.50$ and $0.03-0.58 \mathrm{mg} /$ $\mathrm{kg}$ for milk products and marine smoked fish, respectively.

Boron (overall average $4.41 \mathrm{mg} / \mathrm{kg}$ e.p.) was the sixth element in abundance in table olives. Its content was significantly higher 
in ripe $(5.33 \mathrm{mg} / \mathrm{kg}$ e.p.) with respect to directly brined olives (3.72 $\mathrm{mg} / \mathrm{kg}$ e.p.), while the level in green was intermediate (4.34 $\mathrm{mg} / \mathrm{kg}$ e.p.) (Table 1). An eventual presence of this element in $\mathrm{NaOH}$ solutions might be responsible for its increment as the number of $\mathrm{NaOH}$ treatments (green $<$ ripe) to olives increases. Directly brined Hojiblanca had the lowest content (1.57 mg/kg e.p.), and ripe Manzanilla had the highest (6.82 mg/kg e.p.) (Tables 2-4). The contents of boron in other foods are 28.2 (almond), 27.7 (hazelnuts), 45.1 (raisins), and 21.1 (dried apricots) $\mathrm{mg} / \mathrm{kg}$; the same source attributes $3.5 \mathrm{mg}$ / $\mathrm{kg}$ to olives (50), which is quite similar to the level found in this work. The content in Turkish hazelnuts ranged from 13.8 and $22.2 \mathrm{mg} / \mathrm{kg}(51)$.

The overall Ba content in table olives was $2.77 \mathrm{mg} / \mathrm{kg}$ e.p. Directly brined olives had the lowest significant proportion (1.48 $\mathrm{mg} / \mathrm{kg}$ e.p.), while ripe had the highest (3.91 mg/kg e.p.) (Table 1 and Figure 1). The concentration was fairly similar among cultivars within elaboration styles with the ripe Manzanilla being the presentation with the greatest content $(6.36 \mathrm{mg} / \mathrm{kg}$ e.p. $)$. Reported levels of $\mathrm{Ba}$ in fresh Domat and Memecit Turkish cultivars were fairly lower, 50-319 and 431-513 $\mu \mathrm{g} / \mathrm{kg}(41)$. $\mathrm{Ba}$ in bitter orange and in their marmalades ranged from $<0.001$ to $9.98 \mathrm{mg} / \mathrm{kg}$ and from 0.11 to $0.70 \mathrm{mg} / \mathrm{kg}$, respectively (10).

With respect to elements found in concentrations below 1 $\mathrm{mg} / \mathrm{kg}$ e.p., $\mathrm{Pb}$ was at an average content of $0.37 \mathrm{mg} / \mathrm{kg}$ e.p. (Table 1), which was progressively higher in green, directly brined, and ripe olives, with ripe Cacereña (1.37 mg/kg e.p.) being the presentation with the highest level (Tables 2-4). Proportions of $\mathrm{Pb}$ were slightly lower, apart from the ripe Cacereña exception, than those reported by Şahan et al. (21) for Turkish green $(0.56-0.86 \mathrm{mg} / \mathrm{kg})$ and black olives $(0.51-0.91$ $\mathrm{mg} / \mathrm{kg}$ ). These concentrations are similar to those found by Madejón et al. (52) in the flesh of wild olives, which ranged from 0.20 to $40 \mathrm{mg} / \mathrm{kg}$, depending on the soil and season. Apparently, the levels found in table olives may come from the fruit itself and not from any contamination during processing. However, the use of contaminated chemicals led to high levels of $\mathrm{Pb}(10-31 \mathrm{mg} / \mathrm{kg})$ in darkened by oxidation olives $(53)$. Concentrations in table olives were lower that those found by Demirezen and Aksoy (11) in Turkish vegetables (3.0-10.7 mg/ $\mathrm{kg}$ ), which were related to the contents in the soils, being significantly higher in urban areas. However, contents reported by Radwan and Salama ( 8 ) in a survey of heavy metals in Egyptian fruits $(0.05-0.87 \mathrm{mg} / \mathrm{kg})$ and vegetables $(0.01-0.58$ $\mathrm{mg} / \mathrm{kg}$ ) were of the same order as in olives.

The concentrations of $\mathrm{Cr}, \mathrm{Ni}$, and $\mathrm{Co}$ were at $0.20,0.15$, and $0.12 \mathrm{mg} / \mathrm{kg}$ e.p., respectively. Their proportions were significantly higher in ripe olives (Tables $\mathbf{2 - 4}$ and Figure 1), but no specific trend was found among cultivars. These values were similar to those found by Şahan et al. (21) in Turkish green and black olives and comparable to those reported for fresh fruits from Turkish Domat (Cr, 75-219 $\mu \mathrm{g} / \mathrm{kg}$; Co, 8-15 $\mu \mathrm{g} / \mathrm{kg}$ ) and Memecit $(\mathrm{Cr}, 46-74 \mu \mathrm{g} / \mathrm{kg})$ cultivars (41). Levels of $\mathrm{Ni}$ (3.30-10.50 mg/kg), Cr (0.50-1.60 mg/kg), and Co (0.85-1.45 $\mathrm{mg} / \mathrm{kg}$ ) in potato chips (54) were higher than in olives.

$\mathrm{Cd}$ and $\mathrm{Zr}$ were the elements found in the lowest concentrations in table olives (average $\approx 0.04 \mathrm{mg} / \mathrm{kg}$ e.p.). Significant differences for $\mathrm{Cd}$ (higher in ripe olives) and $\mathrm{Zr}$ (higher in green olives) were found (Table 1 and Figure 1). In wild fresh olives, the $\mathrm{Cd}$ content was fairly low $(0.01-0.54 \mathrm{mg} / \mathrm{kg})$. On the contrary, the use of contaminating chemicals or nonauthorized darkening products has led to a high proportion of $\mathrm{Cd}(3.2-6.4$ $\mathrm{mg} / \mathrm{kg}$ ) in darkened by oxidation Egyptian olives (53). Then, the highest $\mathrm{Cd}$ value in Spanish ripe olives may also come from
Table 5. Estimated Intake Values of Elements, Based on the Consumption of Table Olives Estimated by Cuadrado et al. $(9)^{a}$

\begin{tabular}{|c|c|c|c|c|c|}
\hline element & $\begin{array}{l}\text { average daily } \\
\text { intake from } \\
\text { olives }^{b} \\
\text { (mg/day) }\end{array}$ & $\begin{array}{c}\text { EU MLs (10) } \\
(\mathrm{mg} / \mathrm{kg})\end{array}$ & $\begin{array}{c}\text { JECFA } \\
(24,25) \\
\text { (mg/day) }\end{array}$ & $\begin{array}{c}\text { EGVM } \\
(14) \\
\text { (mg/day) }\end{array}$ & $\begin{array}{c}\text { panel on } \\
\text { micronutrients } \\
\text { (39) (mg/day) }\end{array}$ \\
\hline Al & 0.340 & & $10.00^{d}$ & & \\
\hline B & 0.021 & & & $9.60^{e}$ & $20.00^{f}$ \\
\hline $\mathrm{Ba}$ & 0.013 & & & & \\
\hline $\mathrm{Cd}$ & 0.0002 & $0.05-1.0^{c}$ & $0.07^{d}$ & & \\
\hline Co & 0.0006 & & & $1.40^{e}$ & \\
\hline $\mathrm{Cr}$ & 0.0009 & & & $10.00^{e}$ & $0.025^{g}$ \\
\hline $\mathrm{Li}$ & 0.032 & & & & \\
\hline $\mathrm{Ni}$ & 0.0007 & & & $0.26^{e}$ & $1.00^{f}$ \\
\hline $\mathrm{Pb}$ & 0.002 & $0.020-1.50^{c}$ & & & \\
\hline$S$ & 2 & & & & \\
\hline Sn & $0.002-0.123^{b}$ & $50-200^{c}$ & $140.00^{d}$ & $13.00^{e}$ & \\
\hline $\mathrm{Sr}$ & 0.047 & & & & \\
\hline $\mathrm{Zr}$ & 0.0002 & & & & \\
\hline
\end{tabular}

\begin{abstract}
${ }^{a}$ When appropriate, EU established MLs, recommended daily intakes, safe upper levels, and provisional tolerable upper intakes are also included. ${ }^{b}$ Considering that the average intake of table olives in Spain is $4.8 \mathrm{~g} /$ person/day $(9) .{ }^{C}$ Range of maximum contents in different foods. ${ }^{d}$ Provisional TDI for a $70 \mathrm{~kg}$ adult individual. ${ }^{e}$ Safe upper levels for a $60 \mathrm{~kg}$ adult individual. ${ }^{f}$ Recommended daily intakes for adult individuals. ${ }^{g}$ Tolerable upper intake levels for $60 \mathrm{~kg}$ adult individuals.
\end{abstract}

the chemicals used in ripe olive processing. Cd (0.24-0.94 mg/ $\mathrm{kg}$ ) in Turkish vegetables (11) was also greater than the levels found for olives in this work. The content of $\mathrm{Cd}$ in dietary supplements in México was $0.001-2.90 \mathrm{mg} / \mathrm{kg}$ (7). Levels of $\mathrm{Cd}$ in Turkish green $(0.11-0.15 \mathrm{mg} / \mathrm{kg})$ and black $(0.12-0.16$ $\mathrm{mg} / \mathrm{kg}$ ) (21) were above the contents found in this work, while in fresh Domat they ranged from $<5$ and $35 \mu \mathrm{g} / \mathrm{kg}$ (41). Information on the presence of $\mathrm{Zr}$ in foods is scarce. No explanation for its highest content in green olives can be deduced from this study, although it might be related to the predominant use of unlacquered cans in such style.

On the basis of the average table olive consumption in Madrid estimated by Cuadrado et al. (9), the daily intake of the analyzed elements in Spain was estimated (Table 5). The values were then compared with those limits, recommended daily intakes, or tolerable maximum levels established for some of them (Table 5). The average content of $\mathrm{Cd}$ and $\mathrm{Sn}$ (Table 1) was below the lower limits established by the EU for these elements, except the contents of $\mathrm{Cd}$ for ripe olives, which were slightly above this limit; then, the industry must pay attention to the purity of the chemicals used for processing them. The $\mathrm{Pb}$ content was always fairly close to the lowest limit and within the range established by the EU for this element. Therefore, no concern with respect to the $\mathrm{Cd}$ (except in ripe olives), $\mathrm{Pb}$, or $\mathrm{Sn}$ exceeding the permitted legal limits should arise from this study. In the diet of consumers, low average daily intake of the studied elements from table olives should be expected (Table 5). S would be the highest contributor with about $2 \mathrm{mg} / \mathrm{day}$. It is followed by $\mathrm{Al}$ ( $0.34 \mathrm{mg} / \mathrm{day})$, but even in this case, its contribution would be only about $3.4 \%$ of the provisional tolerable upper daily intake (Table 5). Relatively high daily intakes are also for $\mathrm{Sr}$ or $\mathrm{Li}$, although they are not of any health concern, and the $\mathrm{Sr}$ value is sensibly lower than the reference dose (RfD) established for this element, $36 \mathrm{mg} /$ day for a $60 \mathrm{~kg}$ adult (55). The daily intake of B is far lower than the safe upper level established by EGVM (56) and the recommended daily intake fixed by the Panel on Micronutrients (57). Its contribution and that of Ba to the diet from olives are fairly low with respect to the RfD, $12 \mathrm{mg} /$ day/60 $\mathrm{kg}$ person, established for both by the U.S. EPA (55). Co and $\mathrm{Cr}$ are a reduced proportion of the 


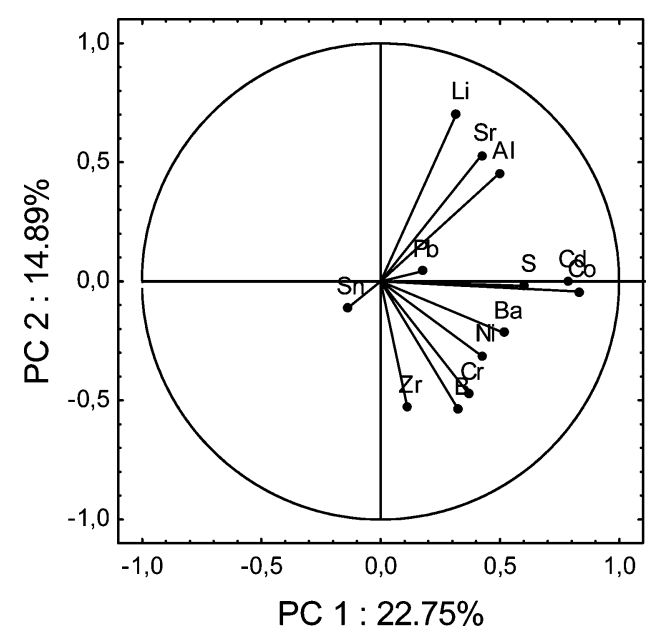

Figure 2. Results of the PCA. Only four eigenvalues higher than 1 were found. The first accounted for $22.75 \%$, and the second accounted for $14.89 \%$ (accumulative variance of $59.86 \%$ of the total). The graph shows the projection (loadings) of the variables (none on labeling mineral elements) on the plane of the two first principal components.

upper safe limits from EGVM (56), and the latter is below the RfD $0.18 \mathrm{mg} /$ day $/ 60 \mathrm{~kg}$ adult as suggested by the U.S. EPA (55). The Ni daily intake for olives is fairly low as compared with the safe upper limit of EGVM (56) or the $1.2 \mathrm{mg} /$ day/60 $\mathrm{kg}$ adult as admitted by the U.S. EPA (55).

Intakes from different styles may vary from the figures shown in Table 5 due to significant differences in concentrations among them (Table 1-4). Some of these differences were clearly disclosed in Figure 1. Such effects were significant for most of the elements, except $\mathrm{Al}, \mathrm{Pb}$, and $\mathrm{S}$. In general, ripe olives were richer in most of the studied elements (Table 1 and Figure 1), except for $\mathrm{Sn}$ and $\mathrm{Zr}$. The increase may be caused by the high presence of such elements in $\mathrm{NaOH}$ and/or other chemicals used in ripe olive processing. This circumstance can be of concern in case of intake restriction for specific elements. The higher presence of $\mathrm{Sn}$ in green olives was clearly associated with their packing in tin-coated cans, which can also contain $\mathrm{Zr}$ as a contaminant.

Chemometric Analysis. The group statistics (averages, standard errors, and $F$ and $P$ values for comparisons) related to elaborations styles are shown in Table 1. There were significant differences among styles for most of the elements, except for $\mathrm{Al}(P=0.442), \mathrm{Pb}(P=0.119)$, and $\mathrm{S}(P=0.803)$. The group statistics for cultivars were calculated similarly (data not shown); in this case, there were also significant differences among cultivars except for $\mathrm{Cd}(P=0.109)$. Then, data showed appropriate characteristics to be subjected to the chemometric analysis.

The correlation matrix between elements showed that there were no strong relationships among them (coefficients $\approx 0.50$ at maximum). The structure was then not prone to achieve a reduction in dimensions. The PCA showed that there were four eigenvalues higher than 1, which accounted for an accumulative variance of $59.86 \%$ of the total. The projection of the variable loadings on the plane defined by the first two PCs (Figure 2) allowed a visualization of the variables and their corresponding correlations, which are the cosine of the angle of their respective vectors $\left(90^{\circ}\right.$ no correlation at all) (58). Thus, $\mathrm{Al}$ is related to $\mathrm{Sr}$ and $\mathrm{Li}$, while $\mathrm{Cd}$ is related to $\mathrm{S}$ and $\mathrm{Co}$; however, the relationships cannot be assigned to concrete causes. On the contrary, Sn can hardly be related to any other, as it corresponds to its specific origin from tin-coated cans. In addition, the projections (loads) of the variables on the PC1 and PC2 axes
Table 6. Confusion Matrix According to Elaboration Styles ${ }^{a}$

\begin{tabular}{lrlllll}
\hline & & \multicolumn{3}{c}{ predicted olive style } & & \\
\cline { 3 - 5 } \multicolumn{1}{c}{$\begin{array}{c}\text { current olive } \\
\text { style }\end{array}$} & $n_{i}$ & green & $\begin{array}{l}\text { directly } \\
\text { brined }\end{array}$ & ripe & $\begin{array}{c}\text { sensitivity } \\
(\%)\end{array}$ & $p_{i}=n / n$ \\
\hline green & 142 & $138(134)$ & $3(7)$ & $1(1)$ & 97.18 & 0.7136 \\
directly brined & 27 & $16(11)$ & $11(8)$ & $0(1)$ & 59.25 & 0.1357 \\
ripe & 30 & $8(11)$ & $0(1)$ & $22(18)$ & 73.33 & 0.1508 \\
total $\left(n_{j}\right)$ & & 162 & 14 & 23 & $n=199$ & \\
specificity (\%) & & 85.19 & 78.57 & 95.65 & & \\
$\alpha_{i}=n_{j} / n$ & & 0.8141 & 0.0070 & 0.1155 & &
\end{tabular}

${ }^{a}$ The DA was based on the element contents in table olives. In parentheses, classification obtained in the cross-validation (jack-knifed matrix). Overall correct classification, 86\%; overall correct classification after cross-validation, $80.4 \%$. Sensitivity (proportion of samples correctly assigned to the group they belong) and specificity (proportion of samples correctly assigned to a group with respect to the total samples classified into it) are estimated only for the classification matrix and not for cross-validation (jack-knifed matrix).

Table 7. Analysis of the Confusion Matrix ${ }^{a}$

\begin{tabular}{|c|c|c|c|c|}
\hline \multirow[b]{2}{*}{$\begin{array}{c}\text { current } \\
\text { olive style }\end{array}$} & \multicolumn{3}{|c|}{ predicted olive style } & \multirow[b]{2}{*}{$Z_{i}$} \\
\hline & green & $\begin{array}{l}\text { directly } \\
\text { brined }\end{array}$ & ripe & \\
\hline green & $8.84(<0.0001)$ & $-21.60(<0.0001)$ & $-22.05(<0.0001)$ & $6.59(<0.0001)$ \\
\hline $\begin{array}{l}\text { directly } \\
\text { brined }\end{array}$ & $18.82(<0.0001)$ & $2.0(=0.0226)$ & $-5.59(<0.0001)$ & $1.88(=0.0301)$ \\
\hline ripe & $4.32(<0.0001)$ & $-6.06(<0.0001)$ & $22.48(<0.0001)$ & $3.02(=0.0013)$ \\
\hline
\end{tabular}

${ }^{a}$ Values of $Z$ and probability (in parentheses) for the analysis of elaboration types $\left(Z_{i}\right)$, rows, and cells. Overall $\chi^{2}=180.55$ with $4,(3-1)(3-1)$, degree of freedom $(P<0.0001)$.

represent their contributions to them. PC1 was mainly related to $\mathrm{Cd}$, $\mathrm{Co}$, and $\mathrm{S}$, but $\mathrm{PC} 2$ was more closely related to $\mathrm{Li}, \mathrm{Sr}$, $\mathrm{Al}, \mathrm{B}$, or $\mathrm{Zr}$. The plot of the case scores on the plane of these two PCs did not lead to their clear separation according to styles or cultivars. Then, data were subsequently subjected to a canonical and DA.

The canonical analysis showed that the elements that most contributed to differentiate among processing styles were Co (54.99, $F$ to remove; 0.616, tolerance), Ba (12.94; 0.935), S (15.91; 0.636), Cr (8.58; 0.976), and Sn (8.03; 0.960), where tolerance is a measure of the redundancy of respective variable in the model (high correlation, small tolerance). The equations of the respective standardized canonical functions using only two decimal figures were as follows:

$$
\begin{aligned}
& \text { function_1 }=0.23 \mathrm{Ba}+1.05 \mathrm{Co}+0.31 \mathrm{Cr}-0.66 \mathrm{~S}-0.28 \mathrm{Sn} \\
& \text { function_2 }=0.75 \mathrm{Ba}-0.54 \mathrm{Co}+0.45 \mathrm{Cr}+0.20 \mathrm{~S}-0.47 \mathrm{Sn}
\end{aligned}
$$

A plot of the case scores vs these functions showed a fairly good separation between samples, although an overlapping between some samples belonging to green and directly brined olives was observed. The procedure reached an overall correct classification of $86 \%$ with $80 \%$ after cross-validation. The correct classification for each style is shown in Table 6. There was a high sensitivity for green $(>97 \%)$ and ripe olives $(>73 \%)$, while specificity was reversed $(>85.19 \%$ for green and $>95 \%$ for ripe olives). Specificity was also moderately high (78\%) in directly brined olives. The main difficulty was the incorrect classification of most of the directly brined olives into green olives and some samples from ripe into green olives (Table 7). Then, an analysis of the results with respect to those expected by chance may be of interest. The overall correct classification observed was $86 \%,(137+10+25) / 199$. The calculus of the expected cases $\left(e_{i j}\right)$ per cell and the overall $\chi^{2}$ lead to a value 
of 180.55 with $P<0.0001$ (with $4 \mathrm{df}$ ) (Table 7). So, it must be concluded that the model performance yielded a better classification into styles than those expected by chance alone.

The test based on the likelihood ratio defined by Morrison (35) can be applied to evaluate the expected classification of specific styles (rows). The values of $p_{i}$. and $\alpha_{j}$, necessary for the calculus of $c_{\text {pro }}$ (expected correct classification by chance), are given in Table 6. The estimated $c_{\text {pro }}$ may be compared with the overall correct classification by the $Z_{i}$ score obtained for each group (style). The $Z_{i}$ values for the respective styles are shown in Table 7. The classification obtained using the model is always significantly better $(P<0.05)$ than that expected by chance. Values in any of the confusion matrix cells may also be tested to determine whether its proportion differs from that which could be obtained by chance. The $Z_{i j}$ values of this comparison and its associated probabilities are shown in Table 7. The correct classification of samples in each style (diagonal) was always higher $(P<0.05)$ than that expected by chance. The misclassification of green as directly brined and ripe olives and the misclassification of directly brined olives as ripe were significantly lower than by chance. The misclassification of directly brined into green was significantly higher than by chance, which means a bias of the model, but its misclassification as ripe was significantly lower. Misclassification of ripe into green was significantly higher than by chance, but the model was able to significantly discriminate between directly brined and ripe olives because the proportion obtained was significantly lower than that eventually obtained by chance. The chemometric analyses using cultivars as grouping variables always led to poor results (data not shown).

This work provides information on minerals that are not required for nutritional labeling in table olives. The research has included the most popular processing styles, cultivars and commercial presentations. The most abundant elements were $\mathrm{S}, \mathrm{Al}$, and $\mathrm{Sn}$, although this element was closely related to a specific style and cultivar (green Manzanilla olives). Most of the elements were found in higher proportions in ripe olives. PCAs showed relationships among some elements, while LDA clearly differentiated green olives from directly brined olives or ripe olives, but these could be confused with green olives. However, directly brined olives and ripe olives were clearly different from one another.

\section{ACKNOWLEDGMENT}

We thank Amparo Cortés for technical assistance.

\section{LITERATURE CITED}

(1) Commission of the European Communities. Commission Regulation (EC) no. 1881/2006 of 19 December 2006, setting levels for certain contaminants in foodstuffs. Off. J. Eur. Union 2006, L364/ $5-\mathrm{L} 364 / 24$.

(2) Institute of Medicine, Food and Nutrition Board. Dietary Reference Intakes: Elements; National Academies. Available at http:// www.iom.edu/Object.File/Master/7/294/0.pdf, 2001.

(3) WHO. Evaluation of Certain Food Additives and Contaminants (41st Report of the Joint FAO/WHO Expert Committee on Food Additive); FAO/WHO Technical Report Series, no. 837; World Health Organization: Geneva, 1993.

(4) Mahaffey, K. R.; Corneliussen, P. E.; Jelinek, C. F.; Fiorino, J. A. Heavy metal exposure from foods. Environ. Health Perspect. 1975, 12, 63-69.

(5) Nasreddine, L.; Parent-Massin, D. Food contamination by metals and pesticides in the European Union. Should we worry. Toxicol. Lett. 2002, 127, 29-41.
(6) SCOOP 3.2.11 (Report of experts participating in task 3.2.11). Assessment of the Dietary Exposure to Arsenic, Cadmium, Lead and Mercury of the Population of the EU Member States; DirectorateGeneral Health and Consumer Protection: Brussels, 2004.

(7) García-Rico, L.; Leyva-Pérez, J.; Jara-Marini, M. E. Content and daily intake of copper, zinc, lead, cadmium, and mercury from dietary supplements in México. Food Chem. Toxicol. 2007, 45, 1599-1605.

(8) Radwan, M. A.; Salama, A. K. Market basket survey for some heavy metals in Egyptian fruits and vegetables. Food Chem. Toxicol. 2006, 44, 1273-1278.

(9) Cuadrado, C.; Kumpulinen, J.; Carbajal, A.; Moreiras, O. Cereals contribution to the total dietary intake of heavy metals in Madrid, Spain. J. Food Compos. Anal. 2000, 13, 495-503.

(10) Rosini-Oliva, S.; Valdés, B.; Mingorance, M. D. Evaluation of some pollutant in bitter orange trees: Implications for human health. Food Chem. Toxicol. 2008, 46, 65-72.

(11) Demirezen, D.; Aksoy, A. Heavy metal levels in vegetables in Turkey are within the safe limits for $\mathrm{Cu}, \mathrm{Zn}, \mathrm{Ni}$ and exceeded for $\mathrm{Cd}$ and Pb. J. Food Qual. 2006, 29, 252-265.

(12) IOOC (International Olive Oil Council). Production of Table Olives; IOOC: Madrid, Spain, 2005.

(13) Garrido-Fernández, A.; Fernández-Díez, M. J.; Adams, R. M. Table Olives. Production and Processing; Chapman and Hall: London, United Kingdom, 1997.

(14) Sánchez Gómez, A. H.; García García, P.; Rejano Navarro, L. Elaboration of table olives. Grasas Aceites 2006, 57, 86-94.

(15) Nosti Vega, M.; Vázquez Ladŕon, R.; de Castro Ramos, R. Composición y valor nutritivo de algunas variedades españolas de aceitunas de mesa. II Aceitunas en salmuera. Grasas Aceites 1979, 30, 93-100.

(16) De Castro Ramos, R.; Nosti Vega, M.; Vázquez Ladrón, R. Composición y valor nutricional de aceitunas de mesa. I. Aceitunas verdes aderezadas. Grasas Aceites 1979, 30, 83-91.

(17) Ünal, K.; Nergiz, C. The effect of table olive preparing methods and storage on the composition and nutritive value of table olives. Grasas Aceites 2003, 54, 71-76.

(18) Biricik, G. F.; Basoglu, F. Determination of mineral contents in some olives (Samanali, Domat, Manzanilla, Ascolana) varities. Gida 2006, 3, 67-75.

(19) López, A.; García, P.; Garrido, A. Multivariate characterisation of table olives according to their mineral nutrient composition. Food Chem. 2008, 106, 369-378.

(20) IOOC (International Olive Oil Council). Trade Standard Applying to Table Olives; COI/OT/NC no. 1; IOOC: Madrid, Spain, 2004.

(21) Şahan, Y.; Basoglu, F.; Gücer, S. ICP-MS analysis of metals (namely: $\mathrm{Mg}, \mathrm{Cr}, \mathrm{Co}, \mathrm{Ni}, \mathrm{Fe}, \mathrm{Zn}, \mathrm{Sn}, \mathrm{Cd}$, and $\mathrm{Pb}$ ) in black and green olive simples from Bursa, Turkey. Food Chem. 2007, 105, 395-399.

(22) Arvanitoyannis, I. S.; Katsota, M. N.; Psarra, E. P.; Soufleros, E. H.; Kallithraka, S. Application of quality control methods for assessing wine authenticity: Use of multivariate analysis (chemometrics). Trends Food Sci. Technol. 1999, 10, 321-336.

(23) Nozal-Nalda, M. J.; Bernal Yagüe, J. L.; Diego Calva, J. C.; Martín Gómez, M. T. Classifying honeys from the Soria Province of Spain via multivariate analysis. Anal. Bioanal. Chem. 2005, 282, 311-319.

(24) Herrera García, M. I.; Pelaéz Puerto, P.; Fresno Baquero, M.; Rodríguez Rodríguez, E.; Darías Martín, J.; Díaz Romero, C. Mineral and trace element concentrations of dairy products from goats' milk produced in Tenerife (Canary Islands). Int. Dairy J. 2006, 16, 182-185.

(25) Anderson, K. A.; Smith, B. W. Use of chemical profiling to differentiate geographic growing origin of raw pistachios. J. Agric. Food Chem. 2005, 53, 410-418.

(26) Alcázar, A.; Pablos, F.; Martín, M. J.; Gustavo González, A. Multivariate characterization of beers according to the mineral content. Talanta 2002, 57, 45-52.

(27) Kelly, S.; Heaton, K.; Hoogewerff, J. Tracing the geographical origin of foods: multielement and multi-isotope analysis. Trends Food Sci. Technol. 2005, 16, 555-567. 
(28) Houba, V. J. G.; Uittenbogaard, J.; Pellen, P. Wageningen Evaluating Programmes for Analytical Laboratories (WEPAL), organisation and purpose. Commun. Soil Sci. Plant Anal. 1996, 27, 421-431.

(29) Kowalski, B. R.; Bender, C. F. Pattern recognition. A powerful approach to interpreting chemical data. J. Am. Chem. Soc. 1972, 94, 5632-5639.

(30) Jackson, J. E. A User'S Guide to Principal Components; Wiley: New York, 1991.

(31) SYSTAT. SYSTAT for Windows, release 10.2.0; Systat Software Inc.: Richmond, CA, 2002.

(32) Uriel, E.; Ardás, J. Análisis Multivariante Aplicado; Thompson España: Madrid, Spain, 2005.

(33) Rencher, A. C. Methods of Multivariate Analysis; John Wiley: New York, 1995.

(34) Smith, S. Discriminant analysis tutorial. Available at http:// marketing.buy.edu/htmlpages/tutorials/discriminat.htm, 2006.

(35) Morrison, D. G. On interpretation in discriminant analysis. $J$. Marketing Res. 1969, 6, 156-163.

(36) StatSoft. Statistica for Windows (Computer Program Manual); StatSoft: Tulsa, OK, 2001.

(37) Anderson, D. L.; Cunningham, W. C.; Lindstrom, T. R. Concentrations and intakes of $\mathrm{H}, \mathrm{B}, \mathrm{S}, \mathrm{K}, \mathrm{Na}, \mathrm{Cl}$, and $\mathrm{NaCl}$ in foods. $J$. Food Compos. Anal. 1994, 7, 59-82.

(38) Saiyed, S. M.; Yokel, R. A. Aluminium content of some foods and food products in the USA, with aluminium food additivies. Food Addit. Contam 2005, 22, 234-244.

(39) Schafer, U.; Seifert, M. Oral intake of aluminium from foodstuffs, food packaging, cookware, and pharmaceutical preparations with respect to dietary regulations. Trace Elem. Electrolytes 2006, 23, $150-161$.

(40) Cabrera, C.; Loris, F.; Giménez, R.; Olalla, M.; López, M. C. Mineral content in legumes and nuts: contribution to the Spanish dietary intake. Sci. Total Environ. 2003, 308, 1-14.

(41) Nergiz, C.; Engez, Y. Compositional variation of olive fruit during ripening. Food Chem. 2000, 69, 55-59.

(42) Codex Alimentarius Commission-Codex Committee on Food Additives and Contaminants. Position Paper on Tin; Food and Agriculture Organization of the UN/World Health Organization: Rome, 1998.

(43) Wehrer, C. Tin concentration in canned fruits and vegetables. Med. Nutr. 1982, 18, 317-324.

(44) Jorhem, L.; Slorach, S. Lead, chromium, tin, iron, and cadmium in welded cans. Food Addit. Contam. 1987, 4, 309-316.

(45) Perring, L.; Basic-Dvorzac, M. Determination of total tin in canned food using inductively coupled plasma atomic emission spectroscopy. Anal. Bioanal. Chem. 2002, 374, 235-243.

(46) Rui, Y. K.; Hao, Y. L.; Zhang, F. S.; Jin, Y. H.; Guo, J. Application of ICP-MS/ICP-AES to detection of 22 trace elements in fruits of elm. Spectrosc. Spectral Anal. 2007, 27, 2111-2113.
(47) Staniskiene, B.; Matusevicius, P.; Budreckiene, R.; Sinkeviciene, I. Trace elements in Lithuanian honey. Veterinarija Zootechnika 2005, 30, 77-82.

(48) Nookabkaew, S.; Rangkadilok, N.; Satayavivad, J. Determination of trace elements in herbal tea and their infusions consumed in Thailand. J. Agric. Food Chem. 2006, 54, 6939-6944.

(49) Nabrzyski, M.; Gajewska, R. Content of strontium, lithium and calcium in selected milk products and in some marine smoked fish. Nahrung 2002, 46, 204-208.

(50) AlgaeCal Boron Reach Foods. Available at http://www.algaecal. com/Boron-Rich-Foods.html, 2007.

(51) Şinşek, A.; Korkmaz, D.; Sedat-Velio, Y.; Yavuz-Ataman, O. Determination of boron in hazelnut (Corylus avellana L.) varieties by inductively coupled plasma optical emission spectrometry and spectrophotometry. Food Chem. 2003, 83, 293-296.

(52) Madejón, P.; Marañon, T.; Murillo, J. M. Biomonitoring of trace elements in the leaves and fruits of wild olive and holm oak trees. Sci. Total Environ. 2006, 355, 187-203.

(53) Ziena, H. M. S.; Yousef, M. M.; Aman, M. E. Quality attributes of the black olives as affected by different darkening methods. Food Chem. 1997, 60, 501-508.

(54) Gopalani, M.; Shahare, M.; Ramteke, D. S.; Wate, S. R. Heavy metal content of potato chips and biscuits from Nagpur city, India. Bull. Environ. Contam. Toxicol. 2007, 79, 384-387.

(55) U.S. EPA. Risk Information System. U.S. Environmental Protection Agency. Available at http://cfpub.epa.gov/ncea/iris/index.cfm, 2007.

(56) EGVM (Expert Group on Vitamins and Mineral). Safe upper levels for vitamins and minerals. Food Standards Agency. Available at http://www.food.gov.uk/multimedia/pdfs/vitmin2003.pdf, 2003.

(57) Panel on Micronutrients, Subcommittees on Upper Reference Levels of Nutrients and on Interpretation and Use of Dietary References Intakes, and the Standing Committee on the Scientific Evaluation of Dietary References Intakes. Food and Nutrition Board. Institute of Medicine. National Academic. Dietary Reference Intakes for Vitamin A, Vitamin K, Arsenic, Boron, Chromium, Copper, Iodine, Iron, Manganese, Molybdenum, Nickel, Silicon, Vanadium, and Zinc; Academic Press: Washington, DC, 2001.

(58) Cichelli, A.; Pertesana, G. P. High-performance liquid chromatography analysis of chlorophylls, pheophytins and carotenoids in virgin olive oil: Chemometric approach to variety classification. J. Chromatogr. 2004, 1046, 141-146.

Received for review June 2, 2008. Revised manuscript received August 8, 2008. Accepted August 11, 2008. This work was supported by CICYT of the Spanish Government (AGL2003-00779 and AGL-2006-03540/ ALI projects, partially financed by European regional development funds, ERDF) and Junta de Andalucía (through financial support to group AGL 125).

JF801690K 